\title{
シンポジウム「歯周病の鑑別診断について, 特に診断
}

\author{
基準と治療効果の面からの検討」
}

演者

追加発言者

司 会 者

\author{
木村吉太郎教授（東京歯科大学保存学教室） \\ 若野洋一助教授 (大阪大学歯学部口腔治療学教室) \\ 木下 四郎教授（東京医科歯科大学歯学部第 2 歯科保存学教室）
}

中静 正教授（愛知学院大学䨑学部歯周病学教室）

加藤 燳助教授 (北海道大学歯学部第 2 保存学教室)

森 克栄歯学士 (東京都開業)

秋吉 正豊教授 (東京医科歯科大学医学部難聴研究施設病理研究 部)

\section{企画の主旨}

\author{
秋 吉 正 豊
}

わが国においては，花沢 (1920)，正木（1926），檜垣 (1934), 木村 (1965), 今川 (1965), 日本歯科医師会 (1966), 今川・石川 (1968) など, 各方面の歯周病学者 によって主として臨床的立場から, 歯槽膿漏(症)すなわ ち歯周病(また米周疾患)の病型の分類が行われている。 これらの分類は個々の点では多少の差異はあっても, 共 通している点としては, 雨周病を炎症性 (型) と骨萎縮 性（型）とに大きく別けていることである。最近の分類 では, 炎症性と骨萎縮性の病変に負担過重による歯周組 織の病変が加えられている。

一方，国外に打いては，欧州に括いても，米国に打い ても, 歯周病に含まれる病型は多くなり, 炎症性歯周 病, 変性性雬周病, 歯周組織の腫瘍のほかに, 歯周組織 の咬合性外傷による病変と, 増殖性病変などが含まれて いる。

臨床的に，歯周病の患者を治療する場合には，まずど のような病型に属し，どのような病期にあたるものであ
るかを，できるだけ正しく診断づけなければ，適切な治 療方針をたて，歯周病を治すことはできない。このため には, それぞれの病型の臨床症状や, 検査の結果から, 鑑別診断に必要な特徵を見出すことがどらしても必要に なる。また一度つけた診断がはたして正しいか否かは， その場合に行なった治療法の効果がどらであったかによ ってある程度判定される。

そこで, 今回のシンポジウムでは, 炎症性の歯周病す なわち，歯周炎と辺縁性雨周炎あるいは炎症型雪槽膿漏 と, 骨萎縮性の歯周病すなわち, 萎縮型または悪性の歯 槽膿漏と, 負担過重性雪周病すなわち, 負担過重型歯槽 膿漏など，それぞれ講演を牤願いした演者の用いておら れる歯周病の分類と, 分類された各病型の診断基準を御 説明いただき，同時に治療法の効果などとの関係の御検 討をいただき，時間が許せば，それらについて討論を行 ないたい。 
講 演 1

\section{東京歯科大学}

木 村 吉太郎教授

一般に正しい治療は正しい診断によって導かれ，正し い診断は正しく行われた診査によって得られる。歯周病 の診断は正にこの通りで, 病名診断, 病型診断, 罹患度 の判定, 予後の判定, ときには類症鑑別診断など, 一度 の診查, 診断の上で, 治療方針が立てられるものであ る。したがって雨周病を扱から臨床家は，まず止周病の 臨床像を十分に理解された上で, 治療に直結する臨床分 類法を採用する。そして罹患度ならびに予後は厳しく判 定して，処置するに当っては，患者の意向を十分尊重し てもこれに捉われたり，いわんや迎合は絶体にしない。

\section{歯槽膿漏患者の臨床分類（木村）}

\begin{tabular}{l}
\hline 分類 \\
\hline 一
\end{tabular}

（歯界展望 $26(4) ： 595-606 ， 1965$. より)
私は長らく花沢奬博士の臨床分類法を採用していたが， 昭和 22 年以降は, 既往症ならびに口腔内所見から成因推 定して, 歯槽膿漏患者を一般型, 悪性型, 過重負担型の 3 型に分類する方法を採用して, 昭和 24 年 10 月, とりあ 兄ず臨床歯科学報第 4 巻, 第 2 号にその内容を発表し, その後, 各型を比較した表を紹介して今日に至ってい る。

本表は一般事項に続いて来院頻度の高い中等症の臨床 所見をもって視診, 触診の順に各型を比較している。殊 に臨床家に対して各型の特長をしっかり覚えてもらう目 的から，あえて混合型といら多分便利でも極めて瞹昧な 病型は入れてない。病勢が進んで症状がいかに他と混合 しても，本来の特長とする病型は失なわないものであ る。したがって臨床上，いかに紛らしい症例も本表によ り順序よく診查すれば，病型鑑別はそれほど困難でない と思らので，本分類を基準にして話を進めてみることに する。

木村教授は歯槽膿漏の臨床的特徴として, 疼 痛がな い，ポケットが $1 \mathrm{~mm}$ 以上の深さを有し，X線フィルムで 骨吸収を認めることなどをあげられた。

歯槽膿漏の病変の程度とポケットの深さ扣よび歯槽骨 の吸収との関係については，次の表を示された。

\begin{tabular}{|c|c|c|c|c|}
\hline \multicolumn{2}{|c|}{ 歯槽膿漏の病変 } & \multirow{2}{*}{$\begin{array}{c}\text { ポケットの深さ } \\
2 \mathrm{~mm} \text { 以上 }\end{array}$} & \multicolumn{2}{|c|}{ 歯槽骨吸収 } \\
\hline 軽 & 症 & & 軽 & 度 \\
\hline 中 等 & 症 & $2 \sim 5 \mathrm{~mm}$ & 中 等 & 度 \\
\hline 重 & 症 & $5 \mathrm{~mm}$ 以上 & & 度 \\
\hline
\end{tabular}

歯肉粘膜のメラニン沈着の白人と日本人との発現頻度 については次の表を示された。

\begin{tabular}{|c|c|c|c|}
\hline & 患 者 数 & 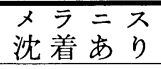 & $\begin{array}{l}\times \bar{\Xi} \\
\text { 沈着なし }\end{array}$ \\
\hline 日 本人 & 100 & 55 & 45 \\
\hline 白 人 & 117 & 19 & 98 \\
\hline
\end{tabular}

また歯槽膿漏患者と健康人とにおける歯肉粘膜のメラ ニン沈着の頻度について次の表を示された。 


\begin{tabular}{l|c|c}
\hline & メラニン沈着あり & メラニン沈着なし \\
\hline 歯槽膿漏患者58名 & $38(66 \%)$ & $20(34 \%)$ \\
健 康 人42名 & $17(40 \%)$ & $25(60 \%)$ \\
\hline
\end{tabular}

さらに，興味ある症例のスライドの供覧があった。

（1）慢性歯肉出血を伴なった歯槽膿漏例

口腔清掃状態は余り悪くなく, 臨床的に正常䨑肉の所 見を示したが，ラバーチップで雨間乳頭を圧迫すると歯 肉出血をきたした。ブラッシングをすすめたが出血は止 まらなかった。そこでさらにブラッシングを注意深く指 導したところ止まった。

\section{講 演 2}

鑑別診断を下すためには，歯周病の病因を解明する必 要があるが，病因はまだ充分明らかにはされていない。 また臨床でなされている検査も主観的なものが多くて, 客観性に乏しいららみがある。このような事情の下で は，歯槽膿漏の診断について述べることは报こがまし い。現在では，まだ，正しい診断をつけるために必要な 検査法が確立されていないのであるが, 臨床では, 毎日 患者を治療してゆかなければならない。

大阪大学では, 歯槽膿漏症の分類について討論してき たが，これまで発表されている分類には臨床に適さない 分類が少なくないことがわかった。歯槽膿漏症の分類 は，客観性があって再現性のあるものであることがよい と考えられる。とりあえず, 1955年の国際歯槽膿漏学会 のとりあげた分類にしたがうことにし, 分類上都合のわ るい部分をかえて用いることにしている。

I Parodontopathia inflammata 炎症性歯周疾患 $=$ Parodontitis 歯周炎

a Parodontitis superficialis 表在性歯周炎

b Parodontitis profunda 深在性歯周炎

II Parodontopathia dystrophica 異栄養性歯周疾患 $=$ Parodontose 歯周症

III Parodontopathia neoplastica 腫瘍性歯周疾患 $=$ Parodontoma 歯周腫
（2）歯槽膿漏の深いポケットから上顎洞炎を引き起こ した症例。上顎大臼歯の深いポケットが同側の上顎副自 腔内に達していた。また生活歯髄を有する歯から起こさ れた副鼻腔炎についても報告された。

（3）歯槽膿漏の場合に口臭を起こすことがあるが，ポ ケットが余り深くなく，ひどい歯槽膿漏もないのに口臭 が強い36歳の婦人の例をよく調べたところ, トリュモナ スの感染によることが明らかにされた。

（4）外科手術によって好結果をえた高度の歯槽膿漏例 および, 著しい増殖性歯肉病変を伴なった青春期性歯肉 炎を全身性のホルモンの影響が加わった肥大性青春期性 雪肉炎として供覧された。(司会者メモより)

\section{大阪大学歯学部}

若 野 洋 一助教授

(口腔病理学 I. 永末, 京都, 1972 )。 この分類からIIIの腫瘍性歯周疾患をはずし， I と II と を用いる。I a の表在性歯周炎は䨑肉の炎症, I b 深在 性歯周炎は非全身性の辺縁性歯周炎, II の歯周症は全身 性非炎症性歯周疾患と解する。

次に歯周病の分類上の鑑別診断の基準については, 診 断を下す個人の主観によるばらつきの少ないものが望ま れる。臨床検査でなにも全身的障害が証明されないもの は, I の炎症性歯周疾患に分類し, 臨㦿検査で何等かの 全身的障害の証明されたものはII の異栄養性歯周疾患に いれることにしている。歯周組織に起こる全身性の老人 性萎縮や廃用性萎縮などもエにいれる。

I b の深在性歯周炎でも, 歯肉の炎症症状は強いもの も, 弱いものもある。また経過をみても, 長いものもあ れば, 短かいものもある。

病変の程度をつけるためには, 歯肉の発赤, 腫脹, 歯 肉ポケットからの出血および排膿，歯間間隙などについ て臨床的に検査した結果を綜合して判定する。

臨床検查の一つとして行われた歯肉の毛細血管ループ の形態変化の観察結果を 10 人の 40 歯について報告され， 臨床検査としての価値を指摘された。

臨床に括いては炎症型の歯周病と非炎症型歯周病とを 鑑別することはむづかしいことで，このためにも，役に 
立つ臨床検査法の確立の必要が望まれることを報告され た。(司会者メモより)

\section{講 演 3}

吾々は日常の臨床に於て, 歯周疾患の分類には今川, 石川分類（1968）に基準を执いている。この分類は蒾周 疾患の原因的事項を配慮した分類方法であり，治療計画 を立てるのに便利であるからである。但し，辺縁性歯周 組織の疾患の分類は, 次のように改良している。i ) 慢 性辺縁性歯周炎, ii）咬合性外傷, iii）混合性歯周炎, iv）歯周症（但し，従来云われているよらな歯周症はあ まりみたことがない)。

歯周疾患の大部分は口腔内の環境の変化によって発生 していると考兄られる。すなわち歯垢, 歯石や食片圧入 などの発炎性因子と，咬合の不調和によっておこる咬合 性外傷や習癖などの機能的な因子によって，歯周疾患は ひき括こされることが多い。歯周疾患の診断に当り, 単 に病名をつけるだけでなく, 原因的事項を考慮して, 治 療計画を立てることによって，診断がなされるものと考 える。全身的の影響が強くて発生する歯周疾患は, その 発生頻度から考えて, 全体の数パーセント以下であると 考えられる。

診断には, (1)現病歷, (2)歯恬や歯石の沈着の程度, (3) 歯肉の炎症の程度, (4)歯周ポケットの深さと型, (5)食片 圧入の有無, (6)歯の咬耗, (7)歯の動摇, 8)歯槽骨吸収の

\section{追加発言 1}

まづ口腔内の一般診查として, 歯肉の形態, 歯苔, ポ ケット, 歯の動摇, 咬耗, 口臭などをよく観察し, さら にX線写真で歯慒骨の吸収をしらべ, 生化学的倹査およ び歯苔の塗抹標本の検索を加えて，歯周組織に起こって いる病変を明か林をとともとれらの病変と原因と

\section{東京医科歯科大学教授}

木下四郎

程度と型, (9)残存雪の咬合状態, (10習癖の有無など, 従 来から重要と考兄られていた事項について診査するのは 勿論であるが，その他に，11歯肉の型，12小带異常や口 腔の軟組織の形態異常の有無, とくに付着歯肉の幅に対 して注目している。歯周疾患に罹患している人の付着歯 肉の幅は, 正常の人より $2 \sim 3 \mathrm{~mm}$ 狭くなっていることが 測定の結果明らかになった。

(13)歯の形態異常, 歯周疾患の進行している部位を観察 すると，しばしばその歯に形態異常があることに気づく ことが多い。例えば, 前霜部の舌側にみられるェナメル 質表面の溝や，日歯部にみられるエナメル質の過形成で ある。後者は根分岐部に迄エナメル質がのびている。こ れらの場合に米肉の炎症がエナメル質表面やエナメル質 の溝に沿って, 急速に歯根部に達して, 歯槽骨の吸収を ひき扤こす。

私共は, (1)から(13)迄の診査事柄の中で, 特に(11)12)(13) 深い考慮を払って診査を進め, 原因的事項の把握に努め ている。

以上のような診断基準にもとづいて治療計画を立て, 治療を行なっている。治療後一週間目から十年以上の経 過した幾つかの症例について, 症例を中心に述べる。

\section{愛知学院大学歯学部}

中 静正教授

の関係をしらべて，歯周病の診断と治療方針をたてるよ らにしなければならない。

歯周病の分類としては, Glickman あるいは, Glickman 飞準じた今川・石川の分類によっている。

Glickman (1965) の分類 
1 Gingival disease

a Uncomplicated gingivitis :

Chronic marginal gingivitis, acute necrotizing ulcerative gingivitis, acute herpetic gingivostomatitis and other viralinfections, allergic gingivitis, nonspecific gingivitis, tuberculosis and syphilis, moniliasis (thrush) and other fungal infections, pyostomatitis vegetans.

b Combined gingivitis :

Dermatoses affecting the gingiva, chronic desquamative gingivitis (gingivosis), chronic menopausal gingivostomatitis, benign mucous membrane pemphigoid.

c Conditioned gingivitis :

Gingivitis in pregnancy and puberty, gingivitis in vitamin $\mathrm{C}$ deficiency, gingivitis in leukemia

d Gingival enlargement :

Inflammatory, noninflammatory hyperplastic, combined, conditioned, neoplastic, developmental.

e Recession :

Gingival atrophy.

2 Periodontal disease (chronic destructive periodontal disease)

a Periodontitis :

Simple periodontitis, compound periodontitis.

b Periodontosis :

Early periodontosis, advanced periodontosis.

c Trauma from occlusion :

d Periodontal atrophy :

Presenile atrophy, disuse atrophy.

(口腔病理学 I. 永末, 京都, 1972.より)

歯周疾患の分類（今川・石川 1968）

A）雬肉の疾患

I ) 歯肉の炎症性病変

1）単純性歯肉炎

2）急性壊死性潰瘍性崡肉炎（および無カタラーゼ 血液症）

3）症候性歯肉炎
a）ホルモン変調
b ）ビタミン欠乏

c）血液病

d）中毒

II ) 歯肉の増殖性病変

a ) 歯肉線維腫症

b ）ダイランチン歯肉增殖症

c）炎症性歯肉増殖症

III）歯肉の退行性病変

a ) 歯肉退縮

b ）慢性剥離性棵肉炎（歯肉症）

付）皮膚口腔粘膜疾患の一部

IV）歯肉の腫瘍

B）辺縁曾周組織の疾患

I）慢性辺縁性歯周炎

II) 咬 合 性 外傷

複合性歯周炎

III）歯周症（打よび PAPILLON-LEFÉVRE 症候群）

（臨床歯周病学，医歯薬，東京，1968より）

次いでスライドによる, 炎症の強い単純性雬肉炎, 米 肉の增殖性病変, 潰瘍性歯肉炎, 複合性歯周炎, 歯周症 などの症例の供覽がなされた。

（1）12歳男児の歯肉象皮病 elephantiasis gingivae. 2 歳から歯肉の栔漫性線維性肥厚があり, 切除して も再発した例。

(2) ワンサン歯肉炎, 22 歳, 婦人, 塗抹標本の検索で fusospirillosis を認め, 薬剤の治療により治療した 例。

（3）鿞漫性歯肉線維症，24歳の例で，炎症を合侀して いた。

（4）急性腎炎に合併した高度の歯肉炎, 腎炎の治療に より 3 カ月で改善された例。

（5）成人の Papillon-Lefévre 症候群, 著明な米槽骨 退縮を起こした例。

最後に，全身的の障害と関連が疑われる歯周病では， まづ局所的原因をよく除去して，その部の歯周組織の病 変がどのような経過をとるかを注意深く観察し，これと ともに臨床検査を行ないどのような全身的障害があるか しらべることが，歯周病の病型の鑑別診断に必要である とのベられた。

急性の経過をとる症例では必ず臨床検査をすることが 望まれる。(司会者メモより) 


\title{
追加発言 2
}

\author{
北海道大学歯学部 \\ 加 藤 熙助教授
}

歯周病の鑑別診断にさいして大切なことは患者の病状 とその病変を扣こした原因（病因）とを正しく把握し， それに基づく正しい診断をくだし，合理的な治療方針を たてることである。病因を考乒ず症状のみから診断をく だし，それに基づいて治療を行ならことは，病因に対す る対策が不十分となりやすく治療効果はあがらず，再発 する結果となる。われわれが遭遇する症例の多くは，局 所的因子が主たる病因であり，それらの病因を見出すた めには, 炎症性因子や外傷性因子などの局所的因子に対 する十分な診査が必要である。今回は追加発言なので局 所因子のなかの外傷性の因子すなわち外傷性咬合の診断 について検討を加えてみたいと思う。

外傷性咬合の症状としては歯の動摇, 咬耗, 顎運動の 異常, 歯槽骨の垂直性の吸収, 歯根膜腔の払大, 骨縁下 ポケット，歯の病的移動，食片圧入などいろいろある が, これらの症状の各は必ずしも外傷性咬合によっての み引き抗ささるとはかぎらず，単に炎症性の破壊によ っても抗こってくる。これらの中の一つの症状の有無か ら単純に外傷性咬合の存在を謬断することは危険であ り，機能的な咬合の診査をあわせて行なうことが大切で ある。

歯の動摇の増加は外傷性咬合の症状のうちでも最も重 要なもののひとつであり, 動摇が異常に增加している場 合には外傷性咬合の存在を疑って, さらに咬合状態, 顎 運動の異常, 歯槽骨の垂直性吸収, X線写真にみられる 雨根膜腔の拡大の有無などを詳しく調べる必要がある。 しかし動摇度は炎症性の病変によっても增加するもので あり,すなわち歯周組織の質的な因子（歯根膜の生物理 学的性質), を量的な因子 (歯根膜線維の 付着している
歯根と菌槽骨の面積）とによって左右され，炎症や外傷 性咬合の除去によりこれらが改善されれば，動摇度は減 少すると考兄らる。外傷性咬合を除く方法としては咬 合調整や矯正的治療法などがあるが雨周組織がある程度 以上破壊されると咬合調整のみでは不十分で歯の固定が 必要となる。

スライドによる症例の供覽がなされた。

(1) ジランチン歯周增殖症, ジランチン投与例に怙け る歯肉增殖の頻度は 54 4 62\%である。ネコで行なっ たジランチン投与実験では, 局所の炎症がつよい歯 肉では增殖が起こっていた。したがってジランチン の全身的影響のようにみえるジランチン歯肉增殖症 の発生には局所の炎症による影響が大きいことを指 摘された。治療面ではこの場合にブラッシングによ る著しい改善がみられるといら。

（2）複合性歯周炎を疑わした症例。ブラッシングと咬 合改善の局所的治療でよくなった。

（3）はぎしり bruxism. つよく食いしばることによる 異常咬合圧の作用に炎症が加わると広範な歯槽骨の 吸収が起こるはぎしりの原因には精神的影響が大き いと考えられるので, 精神的なストレスを緩和する ことが大切である。

最後に, 若年者にみられる高度の歯周疾患はとかく全 身的影響によると考学がちであるが，局所的原因を注意 深く除去するだけでよくなる症例があるので, 局所的原 因による歯周疾患と，全身的原因が加わった雨周疾患の 鑑別には，治療による効果を十分注意することも必要で あることを指摘された。(司会者メモより) 


\section{追加発言 3}

$$
\begin{array}{ccc}
\text { 東 京 都 開 } & \text { 業 } & \\
\text { 森 } & \text { 克 栄歯学土 }
\end{array}
$$

㐘周病は複雑な要因から成立ち, その病因の分析と理 解についての重要性, 正しい診断と合理的な治療方針に ついては, いくら詳しく論じても言尽されないと思いま す。臨床で日常相遇する症例は, 歯周病のみに罹患した ものが少ないからでありましょう。

一般に䶢蝕と歯槽膿漏が雨科の二大疾患としてあげら れてきましたが，口腔全体の治療を対照とした症例では 医原性疾患による再治療を要する比率が非常に大きく占 め, 臨床に扎いて治療方針をたてる場合必ずしも容易で はなく，またその経過の判定で治療方針の変更を余儀な く迫られる場合がある。これらの理由は, 術式の不手際 や，患者に期待した協力が不充分であったり，また患者 の全身的な要因を把握できなかったことなどが考兄られ ます。特に, 細分化した歯科専門諸分野の臨床に調和の 必要性が強調されねばならない。例えば一口腔内に歯周 病の治療が首尾よく施されても, 補経の分野に欠点があ れば臨床に和いては失敗例に終ってしまう。

雨科一般を取扱う臨床家の一人としては, 常に初期の 霜周病の発見とその治療と, 予防歯周病学的な治療とに 積極的な態度を確立するように心掛けている。しかしそ れは理想的なことで，その実現は難しいことを痛感して いる。勿論, 中等度以上の歯周疾患をもつ患者も数多く 取扱わ齐ばならず，これらの症例はいわゆる咬合性歯周 炎 (Occlusal periodontitis) と診断される場合が多く,

\section{シンポジウムのまとめ}

歯周病または歯周疾患あるいは歯槽膿漏（症）の病型 の鑑別診断をつける場合には，雪周組織に起こされてい る病変の現状を正しくとらえることが必要であることは 勿論であるが，それとともに，現在の病変にいたる 経 過, および種々なる局所的因子の除去, 局所的条件の改 善などによる病変の影響をみながら局所的原因の病変に
この治療方針の一般的傾向を述べさせて頂く予定です。 先づこの Occlusal periodontitis について, 歯周病の 種々な病名の中で位置づけを解説し, その治療方針には

1）予備的治療

2) 再診断

3）積極的治療（外科的処置を含む）

4) 機能的咬合の回復と調和

5)メインテナンスとリコール

以上を順に大略紹介し, 適時臨床の記録写真を供覧し 御批判を賜りたい。

また，歯髄と歯周組織の相関々係が臨床的に諸相を呈 する。その診断法と治療方針に関する再検討を時間が許 せば試みてみたい。治療前後および予後に関する資料を スライドで提出し, シンポジゥムに参加される諸先生に 討論の出発点とさせて頂きたい。

参考 : 森 克栄 : 歯周疾患と根管治療, 歯界展望 $39 \cdot(4) 726,1972$

スライドによる症例の供覧があった。

演者は特に, 歯科医によって行なわれた歯周病の不適 正治療によって, 歯周病が作られたり, 悪化される症例 がしばしばみられることから, 歯周病の治療をまかされ ている臨床家は常にこの点に注意をはらい, 新しい局所 的誘因をつくることのないように心掛けるよう注意を喚 起した。（司会者メモより）

司会者秋吉 正 豊

対する影響力の大きさを正しく評価することが必要であ る。

局所的治療（局所的原因および局所的誘因の除去, 軽 減) の病变におよぼす効果の面から検討してみると， brushing, scaling, flap operation, 歯肉縁形態の形成手 術, 咬合調整などで, 霜肉縁部の歯頸部や䨑肉囊内の歯 
石や菌苔を除去したり，歯肉囊をなくしたり，歯肉縁の 形態を正常状態に近くしたり, 異常咬合圧の作用を軽減 したりなくしたりするだけで，治療する症例の多いこと を教示されたことは意義深いと考えられる。

一見, 臨床所見では, 非炎症性の歯周症を疑わすょう な場合でも，よく前歴をとって病変の経過をみることに よって，その病変が全身的障害によるものではなく，局 所的原因によって起こされることが明かになる症例も示 された。また， brushing は歯苔を除去するのにきわめ て効果的手段と考兄られがちであるが，指導がよくない 場合には，歯苔除去が十分行なわれず，局所的原因の作 用が改善されにくいことも示された。

臨床所見をみる場合に注意しなければならないこと は, 病変の経過の 1 時点に和ける症状だけに目をらばわ れないで, 病変を経過としてとらえようとする心構えで ある。したがって, 同じ個人の病変であっても, 炎症症 状は軽いことも強いこともあり，歯肉の退縮や歯槽骨の 吸収の程度もますまであり，炎症症状と歯肉や歯槽骨の
退縮との関係もいろいろであることも示された。 全身的障害による来周症の診断をつけるためには，前 述したような，局所的原因の除去や局所的誘因の改善を まづ行ならことが必要であるが，同時に臨床検査（生化 学的, 生理学的, 血清学的, 細菌学的, 病理学的など の）によって全身的障害の存在と，その程度および歯周 組織に対する影響のしかたなどを明かにする必要がある ことが指摘された。

しかしながらこのような目的にかなった臨床検查法 は残念ながらまだ確立されていないので，今後の重要な 課題の一つである。

付記 このシンポシウムムの記事は，各演者の抄録と当日 の司会者のメモをむとにして編集したものである が，木下四郎教授の講演抄録はシンポジウム後に 提出いただいたものである。

参加された先生方の御協力に心から感謝する。 